\title{
correspondence
}

\section{Fast reactors do produce 60 times more energy than thermal reactors}

SIR,-Despite Dr Jeffery's reference to "nuclear nonsense" (13 September, page 98), fast reactors do produce about 60 times more energy from the same quantity of uranium than do thermal reactors. The full reduction in uranium demand brought about by the introduction of fast reactors into a power system will not be achieved until all the thermal reactors have been replaced by fast reactors. The rate of replacement depends on many factors, including the particular rate of growth of the electricity demand, the breeding gain of the fast reactor, and the amount of plutonium needed for the initial charge of each reactor. For the particular parameters used in the calculations quoted by Dr Jeffery, uranium ore demand up to the year 2020 was reduced by a factor of 1.7 , but he did not point out that some $10-15$ years later there would be no need for any further uranium imports: a situation which would continue for centuries.

Dr Jeffery quotes calculations by Grainger and Merrick based on a $5.5 \%$ exponential growth rate. Such a high growth rate could not be sustained over a long period: it is about double the average growth rate over the last decade and would result by 2020 in a near 10 -fold increase of the present installed generating capacity and a fuel consumption of $10^{9}$ tonnes coal equivalent per year.

If a growth rate of much above $3 \%$ were to be maintained for one or two decades, two factors would become important. Firstly, reactor designs (which already exist) with better breeding performance than those currently specified, would be favoured. (Even the current designs have a better breeding performance than that assumed by Grainger and Merrick.) Secondly, the rate of introduction of fast reactors could be increased by fuelling some of the new reactors with $\mathrm{U}^{235}$ instead of plutonium. Even for a growth rate as high as $5.5 \%$ it would then still be possible to reduce uranium imports to zero within a few decades.

$$
\text { Yours faithfully, }
$$

UKAEA, Risley, UK

R D SMITH

\section{The National Computing Centre is not a quango}

SIR, - I support the point made in your leader 'Hunting the Quangos' (2 August); Quasi Autonomous non-Governmental

Organisations have undertaken many essential tasks in the public interest more effectively and for less cost than would have been the case if government departments had been used.

However, the inclusion of the National Computing Centre in your list of Quangos is incorrect. We could debate whether, or not, it ever was a Quango, depending on one's choice of definitions, but there is no doubt that today there is nothing 'Quasi' about the NCC's autonomous state.

In March 1978 an Extraordinary General Meeting changed the status of NCC from a grant-aided body to full independence. Monies received from government sources (about a quarter of the budgeted revenue of $£ 4.4$ million) are in payment for contracts or projects undertaken on behalf of government departments. A definition of Quangos on this basis would include many independent commercial or industrial organisations which undertake government contracts.

The only formal link with government in the present NCC constitution is the Secretary of State for Industry's power to recommend two directors (out of 19) and approve changes to the constitution. In no way does this influence the independence of NCC in its day to day activities, which, incidentally, include export earnings of nearly $£ 300,000$. Yours faithfully,

D FIRNBERG The National Computing Centre, Manchester, UK

\section{Farm or laboratory for male chicks?}

SIR, - Lord Halsbury considers the problems of animals on farms and in laboratories to be very different (16 August, page 534). There is however, an important case where the two are directly related. I refer to the neonate male chick (Gallus gallus domesticus) as an alternative to mammals for large-scale toxicity tests and other laboratory purposes. Farms in the United States alone have more than 275 million laying hens of strains developed to produce eggs at a minimum cost. Since the males of these strains have no commercial value (their meat is tough and stringy) they are destroyed after hatching. Thus, the males (cockerels) are a waste product, available in numbers exceeding 200 million per year in the United States alone. The chick offers advantages of low initial cost (approximately $\$ 0.20$ each compared with $\$ 1.50$ for mice and $\$ 4.50$ for rats) and low maintenance costs. Presumably, converting cockerels from a waste farm product to a source of income could also lead to lower prices for eggs.

There is ample precedent for laboratory uses of the chick, eg, Russell et al. (Toxicol. Appl. Pharmacol. 2, 558: 1960) compared the mouse and chick in toxicity determinations and Spooner and Winters (Int, $J$

Neuropharmacol. $5 ; 217 ; 1966)$ reported an extensive neuropharmacological profile of the chick. It would appear to be relatively staightforward for laboratories using large numbers of mammals to compare the chick with the mammalian model under their conditions. Similarities and differences will be found; each could prove useful.

A second suggestion for reducing the consumption of laboratory mammals is employment, where feasible, of the Dixon and Massey (Introduction to Statistical Analysis, McGraw-Hill, New York, 1957) "up-anddown" technique. This permits a $30-40 \%$ reduction in the number of animals required for an LD50 determination and is applicable to other tests, as well. A drawback which constrain applicability is that the effect upon a given animal must be known before the next animal can be tested.

While all living things should be protected from abuse, the Cruelty to Animals Act of 1876 recognised the differential attitudes of the public toward treatment of "cuddlesome pets" and of invertebrates. I suggest that resort to non-mammalian species, and to techniques which reduce the number of animals used in laboratories, might at least mitigate objection by the general public to the use of experimental animals. Your faithfully,

Sepulveda, California, US

Arthur Cherkin

\section{Falsification of facts}

SIR, - I have to disagree strongly with the letter by Lee Lorch (Nature, Vol 281, 13 September, page 98) on "Biased reporting of East European Science". My field of work is astronautics. In spite of all their activity, in this field and numerous international meetings, information from so-called Socialist bloc countries is nearly without value - ask any NASA international expert. There are some limited subject areas only (biomedical, and strictly scientific results), where my sweeping statement does not hold.

Any GDR citizen can visit the FRG, as far as the letter is concerned. It is the GDR which does not permit their citizens to travel freely. The accusation as stated by Larch is a gross falsification of the facts as they exist now since the shameful Berlin wall was built. Since this knowledge is widely available, I hold spreading of such disinformation to be irresponsible.

"Frustration and pessimism"' is an exact description of the general mood in Soviet occupied Germany. I travel there quite frequently. Possibly Lorch does not speak German or succeeded in scaring his contact persons (easily done: they know the world they are condemnned to live in), so they were afraid of speaking freely.

Since I plan to continue travelling to East European countries, and to keep up the cordial personal relationship I enjoy with several scientists there, I ask that my name and affiliation be withheld.

\section{Disillusionment with UK industry}

SIR, - I wholeheartedly agree with the comments made in the article about Barry Francis and the engineering profession (9 August, page 442).

I became so disillusioned with British industry that I packed my bags and took my wife 4,000 miles west to the USA. Here I find that engineers enjoy a much better standing in society and those I encounter in industry hunger for the latest design and analysis techniques. Their appetite for using current research results contrasts so markedly with the conservative approach and outdated ideas so prevalent among British organisations. This is probably the reason why the UK is termed Britain, rather than Great Britain. We no longer have the great engineers like Brunel, Watt and Stephenson and I don't see them materialising until many of the ideas indicated towards the end of the article are implemented. Your faithfully, BRIAN S THOMPSON

Wayne State University, Detroit, US 